$\triangle$ CTA NEOPHILOLOGICA

DOI: 10.4312/an.53.1-2.133-151
UDK: 821.111(73).09Hemingway E.:" 82.09(497.4)"1990/...

\title{
Ernest Hemingway in Slovenia since 1990: Scandal, the Soča and Six-Toed Cats
}

\section{Simon Zupan}

\begin{abstract}
The position of Ernest Hemingway in Slovenian culture in the pre-1990 period was systematically examined by Maver (1990). Developments since then, however, have not yet been researched in a synthetic manner. The article analyzes three aspects of Hemingway's presence in Slovenia: literary-critical reception of his works in Slovenia after 1990; his position in Slovenian popular culture; and the statistical data about the number of book loans for his books in Slovenian libraries. The analyses confirm that Hemingway's position in Slovenia has not changed dramatically and that he remains recognized as one of the foremost $20^{\text {th }}$ century American writers.
\end{abstract}

Keywords: Ernest Hemingway, literary reception, literary criticism, popular culture, book loans 


\section{INTRODUCTION}

Ernest Hemingway (1899-1961) has been a prominent international literary figure for decades. In some European countries, his name and even translations began to appear in the 1920s (e.g., Heller 1992: 27, Winther 1992: 20, Lundén 1992: 51), not long after his first works were published in English (see Reynolds 2000). Slovenian readers, on the other hand, first encountered his name in $1932^{1}$, when the literary monthly Dom in svet reviewed Jack London's novel The Valley of the Moon. Although the reviewer Boris Orel primarily focused on London's novel, he also mentioned several contemporary American writers, including Hemingway. It was notable that, according to Orel, the response to Hemingway and his contemporaries in Europe had been lukewarm because they were - "too European" (Orel 1932, 330). Hemingway's status in Slovenia before World War Two substantiated that observation, given that his presence remained limited to a few sporadic (meta-)literary references. After the war, however, the situation changed. Once Hemingway's texts became available in Slovenian translation, he soon became not only a well-known author but also a celebrity, and ultimately "a very popular novelist among the Slovenians” (Maver 1990, 62). Hemingway's position in the Slovenian literary system and culture in the pre-1990 period has been examined by Maver, whose research followed three distinct lines: the general response to Hemingway in Slovenia; the response of Slovenian literary critics to his work; and the reputed presence of Hemingway on the Isonzo front during WWI (Maver 1990). No attempt has since been made to synthesize Hemingway's position in Slovenia after 1990, and the present study aims to partly fill that void. Following the Introduction, the central part of the article comprises three sections with subsections: section 2.1 includes an analysis of two afterwords from the new book editions of Hemingway; section 2.2 examines Hemingway's perception in Slovenian popular culture across three different thematic domains (2.2.1-2.4.1); while section 2.3 comprises an analysis of the book loans for Hemingway in Slovenia over the last twenty years. The article closes with the Conclusions.

\section{HEMINGWAY IN SLOVENIA SINCE 1990: AN OVERVIEW}

As was the case with the preceding three decades (cf. Maver 1990), the period between 1990 and 2019 was relatively vibrant for Hemingway in Slovenia. In terms

1 According to Maver (1990, 51), Hemingway's name first appeared in Slovenia in 1933 in an index of banned books in Germany, which was regularly updated by the literary monthly Ljubljanski zvon; however, recent findings showed that Hemingway had been referred to by Orel (1932) at least one year earlier. 
of book editions, the range of his fiction in Slovenian expanded, with nine new books, including a new (second) translation of The Old Man and the Sea (Hemingway 2011) and a collection of short stories Big Two-Hearted River (Hemingway 2010) comprising seven old translations by Janez Gradišnik and six new ones by Miriam Drev; the remaining seven books were reprints of existing translations ${ }^{2}$. In addition, three of his non-fiction works were translated ${ }^{3}$. This dynamics could not compare to the three decades leading up to 1990, when over twenty books of Hemingway's prose came out in Slovenian; however, given that most of his fiction was already available in translation by $1990^{4}$, it is understandable that the frequency of new editions eventually decreased.

Equally dynamic was the response to Hemingway and his works in Slovenia in the same period. In addition to two comprehensive literary essays published as Afterwords, two unpublished doctoral dissertations on Hemingway were compiled (Kern Slapar 2009; Zupan 2009) and at least two dozen MA and BA theses. Among more recent publications, it is necessary to mention a study by Johnston (2019), in which she sought parallels between Hemingway's famous "Iceberg Theory" writing style and the role Slovenes and Friuli play under the surface of his novel $A$ Farewell to Arms. Given Hemingway's status, it comes as no surprise that quantitatively, the highest number of publications about him fell in the domain of popular culture, proving that Hemingway had retained the status of a near-celebrity. Slovenian daily newspapers, for example, published dozens of items about his life and work including commemorative articles marking anniversaries of Hemingway's death; popular speculation about his reported presence in what is now Slovenian territory during World War I; news reporting new international publications about Hemingway; as well as updates on marginal subjects, ranging from the Hemingway family cats to new cocktails named after the famous writer. In fact, it turns out that it is nearly impossible to find a newspaper in Slovenia not mentioning Hemingway occasionally in one context or the other. Although the latter contributions have limited scholarly value, they nevertheless form an integral part of the construct of Hemingway as an international cultural artefact in Slovenia.

2 For Whom the Bell Tolls (1998, 2004, 2005), A Farewell to Arms (1991, 2004a), The Sun Also Rises (1991a) and To Have and Have Not (1991b).

3 Green Hills of Africa (Hemingway 1991c), A Moveable Feast (Hemingway 1991d), and True at First Light (Hemingway 2000).

4 To date, a total of thirty-one book editions of Hemingway's fiction have been published in Slovenian, including eight of his ten major novels and novellas and more than thirty of his nearly fifty short stories. 


\section{Afterwords}

Of the nine new book editions of Hemingway's fiction, two included afterwords. By definition, afterwords comprise the following main elements: presentation of the author, the origin of the text and its presentation (or interpretation) (Glušič cit. in Grosman 1997, 45); in turn, afterwords are indicative of the literary-critical perception of a particular work in a given period. Each text about Hemingway was the work of an established Slovenian literary critic and scholar. The first was written by Vanesa Matajc (1998) and included in the 1998 reprint of For Whom the Bell Tolls; the second was by Matej Bogataj (2010) and was part of the short fiction collection Big Two-Hearted River. The other books, not even the new translation of Old Man and the Sea (2011), had no accompanying texts ${ }^{5}$. Both new afterwords were extensive and comprehensive, complying with the requirements of the genre.

In the introductory part of the essay entitled "Hemingway or the last visions of immortality", Matajc (1998) presents in great detail the history of the Spanish Civil War, its main protagonists and Hemingway's personal experience in it, providing a backdrop for her analysis. She points out that, although Hemingway held a pacifist and neutral position, maintaining that "every war is bad" ${ }^{6}$, he left Spain convinced that Communist Machiavellianism was a necessary evil under the circumstances, an awareness "that deeply troubles Jordan from For Whom the Bell Tolls" (Matajc 1990: 493). According to Matajc, the tragic ending would suggest that For Whom The Bell Tolls is a "novel of disillusionment" (498); however, the story predominantly affirms the motivation behind the Republican resistance, intensively testifying "to the tragic split between historical reality and the individual's illusion of it" (499). Matajc also analyzes the novel from a literary theoretical standpoint. She highlights the brief time span of the story, comprising three days and nights, which means that it could have been narrated as a longer novella (ibid.). As a comparative literature scholar, Matajc examines the position of the novel in contemporary world literature, placing it in the vein of André Malraux's literature of "man's fate" in France. She maintains that, in contrast to the pessimistic and "meaningless freedom in the world of disintegrated sense and moral order" (500) of the Lost Generation, the individual in For Whom the Bell Tolls, embodied by Robert Jordan, becomes more sophisticated in reflecting on his tragic human

5 The absence of forewords or afterwords in other editions is not surprising. After 1990, the publishing market in Slovenia experienced difficulties because of increasing, often unfair, competition, forcing many publishers to further lower the costs. As a side effect, fewer new literary translations and afterwords were being commissioned.

6 Unless indicated otherwise, quotations were translated from Slovenian into English by the author of the article. 
existence, deliberately exposing himself to danger and, aware of his own mortality, taking his love of life to the extreme (501). Other main protagonists of the novel are examined in a similar way.

In her conclusion, Matajc largely subscribes to the observation of another prominent Slovenian literary scholar, Janko Kos, from the 1964 edition of the novel that "almost all literary scholars agree that [Hemingway's] inner scope and importance are not at the level of the most prominent writers of the $20^{\text {th }}$ century" (Kos 1964, 5). Matajc agrees with Kos that Hemingway craftily combined the elements of traditional and Modernist prose, added to which were idiosyncratic stylistic features such as the simple and terse language (Matajc 1998, 510). However, in contrast to Kos, who problematizes the fact that the novel "is not an exhaustive, and even less so comprehensive representation of the political and social developments that are the cornerstone of the main story" (Kos 1964, 24), Matajc points out that the novel "is not about History as such but about the individual in it: his experiences and feelings more than a logically-controlled reflection" (Matajc 1998: 510). In turn, the novel is not socio-politically engaged; instead, it transposes the dehumanizing effect of killing for both the victim and the perpetrator not only in the Spanish Civil War but in any other military conflict.

In his essay entitled "The Enigma of Hemingway - Papa and a rebel son in one”, Bogataj first outlines Hemingway's life, claiming it would be difficult to understand his writing without knowing his life and personality $(2010,204)$. He mentions Hemingway's individualism, escapism, rebellious character, and the health problems that plagued him for years but also his cultivation of a middle-class lifestyle. Bogataj's Afterword is one of the few published in Slovenia that mentions Hemingway's possible homoerotic traits. In addition to For Whom the Bell Tolls, Bogataj praises Hemingway's shorter fiction, such as The Old Man and the Sea, "The Snows of Kilimanjaro" and "The Short Happy Life of Francis Macomber" as "no doubt quality literature" (Bogataj 2010, 205). According to him, Hemingway builds on Mark Twain's tradition, particularly that of Huckleberry Finn and the mimetic qualities of the dialogue in it. As was the case with Matajc, Bogataj also cites Kos' (1964) essay, thus indicating its continuing impact fifty years on.

The rest of the Afterword is a presentation and literary evaluation of some of the short stories in the collection. Bogataj singles out "Indian Camp" ("Indijanski tabor"), which according to him, is an "initiation story, a simultaneous presentation of being born and dying" (Bogataj 2010, 208). Although the initiation fails after Nick sees more than he can take, Nick arrives at a general conclusion that "he will never die" (ibid.). Also highlighted is "The Sea Change" ("Preobrat") because of its "terse Hemingwayesque dialogue, almost playwriting style with little 
narration” (209). In “The Snows of Kilimanjaro” (“Sneg na Kilimandžaru”), Bogataj highlights the use of Modernist interior monologue in combination with realistic objective narrative. By switching between the two, Hemingway creates intense dialogue reflecting the difficult relationship between partners, on the one hand, and the occasional excursions of the protagonist into his past in Austria, Switzerland and elsewhere (Bogataj 2010, 214). According to Bogataj, one of the most significant stories in the collection is "The Short Happy Life of Francis Macomber", "the most typical example of Hemingway's existentialism" (215). The story portrays "a dysfunctional couple glued together by affluence and elitism, who are at an advanced stage of mutual humiliation and permanent imposition and assertion of hierarchy between the two partners" (ibid.). According to Bogataj, Margot is representative of the powerful but demonized women in Hemingway's prose; Francis, on the other hand, is a typically weak and cowardly inexperienced man, resembling people that surrounded Hemingway in his birth family (215216). Bogataj's conclusion is even more affirmative than Matajc's. He claims that "such men [as Hemingway] are no longer made" (217). Although opinions of Hemingway and his work are often divided, he is "a living and provocative author, not merely a mid- $20^{\text {th }}$ century literary giant copied by many and followed by even more grateful readers" (ibid.).

Although representing a small sample, the two essays are indicative of the evolution of literary criticism of Hemingway in Slovenia over the last few decades. In 1952, for example, Juš Kozak, the then established Slovenian writer and literary critic, published an extensive essay on contemporary literature, including a long passage on Hemingway. Referring to For Whom the Bell Tolls, Kozak quotes a fellow-Partisan fighter according to whom "it took an American to describe the Partisan struggle for freedom as we had experienced it but in vain expected our writers to depict" (Kozak 1952, 402). In the same essay, Kozak also wonders why the same novel "is so appealing to our readers, in particular the Partisans" (404); he writes about Pablo, a protagonist in the novel, as a "dialectical portrayal of human development" (403); and queries whether "[the protagonists of the novel] are typical, as realism demands" (ibid.). In addition to showing Hemingway's popularity, the quotations reveal the then powerful aesthetic of social realism and the underlying political ideology of the time, which did occasionally seep into literary scholarship. Of course, not all contemporary Slovenian scholars and critics shared those views. Nevertheless, the contrast between Kozak and the post-1990 scholarly and critical writing about Hemingway in Slovenia reveals that modern critical writing largely converges with that of the English-speaking world from about the same period (cf. Donaldson, 1996). 


\section{Hemingway in Slovenian popular culture}

Besides the literary connoisseurs, Hemingway has always been a magnet for the general public and the popular press. What distinguishes him from most other writers is that "[e]ven those who have never read a word he has written, in school or college or on their own, are aware of his presence in the world of celebrity - a rugged macho figure called Papa with a signature white beard" (Donaldson, 1996, 1). As a result, the media have always been keen to keep the readers posted about him, Slovenia being no exception. In the 1930s and 1940s, for example, Hemingway's appearance in the Slovenian print media was limited, restricted to an odd reference to his name in the context of contemporary American literature ${ }^{7}$. However, following the publication of the first translations of his texts in the early 1950s and his Nobel Prize for Literature in 1954, Hemingway's popularity increased. Suddenly, Slovenian newspapers and magazines started updating their readers with news such as his hunting expeditions in Africa (Bohanec 1953); his alleged extramarital romantic relationships ("Škandal okrog avtorja" 1951); the upcoming movies based on his fiction ("Zapiski" 1951); and the exorbitant fees for his film scripts ("Hollywoodski honorarji" 1954). Bibliographic records show that in the 1950s and 1960s, over a hundred such items appeared in Slovenian printed media alongside the book reviews (Zupan 2009).

After 1990, this situation did not change much. A search through the electronic editions of the three main national daily newspapers in Slovenia, Delo ${ }^{8}$, Dnernik and Večrer of the last 15 years $^{9}$ yielded over 40 news items relating specifically to Hemingway and many more that mention him in passing. The range of topics is wide, comprising the following three main groups.

\section{Hemingway and the Isonzo Front}

As was the case before 1990 (cf. McIver 1988; Maver 1990), one of the most intriguing questions for the media remained Hemingway's alleged presence in what is now Slovenian territory during World War I. Following an extensive article in

$7 \quad$ Examples include frequent updates about banned American books in Nazi Germany, such as "Pisatelji na indeksu" (1933), or an observation in passing that Hemingway was a friend and contemporary of John dos Passos (Fatur, 1936).

8 The Delo online database also includes its affiliated publications, such as the magazine Polet or the tabloid Slovenske novice, which also published Hemingway-related items and were included in the study.

9 The year 2004 was a cut-off point because by about the end of that year half of Slovenian households had access to the internet and almost 40 per cent of users were accessing online newspapers (“Uporaba IKT” 2006, 6). 
Primorski dnevnik in the late 1980s (Jeranko 1988), which left that possibility open, Torkar (1992), mostly relying on a short scholarly paper by McIver (1988), once again dismissed that claim, accentuating that Hemingway "never came within 100 kilometers of Gorizia" (Torkar 1992). Waltritsch revisited the same subject in a long article in 1999. He wrote that he was aware of the stories circulating in the Soča valley: that Hemingway had slept in a tent pitched in the front yard of a local tavern; that he had drunk under the table the local competition with 14 glasses of rum; or that there was even some Hemingway blood running in the veins of the locals (Waltritsch 1999, 12). However, according to Waltritsch, had these stories been true, "Kobarid [Caporetto] would have become the new pilgrimage Mecca of Hemingway's Slovenian fan club" (ibid.). Instead, as the author explains, Hemingway had access to several personal accounts by English officers and medical staff who did see the Isonzo front, skillfully turning them into a novel (ibid.), an interpretation that is accepted by modern Hemingway scholars (see Rennie 2018).

Despite these efforts, the myth persisted. Its tenacity showed a decade later, when an entire monograph was dedicated to the same subject (Drekonja and Jankovič Potočnik 2009). Its authors took the effort to debunk the myth even more thoroughly than their predecessors. After meticulously studying the geography of the "Slovenian" setting in the novel, they endeavored to retrace the microlocations referred to in the book in the field. The authors found Hemingway's descriptions surprisingly accurate, allowing them, for example, to locate the house in which Frederic Henry's unit from the novel was located in Gorizia. However, as was established elsewhere (e.g., Vernon 2013, 390), the authors found that Hemingway could not have been in the area during the decisive Austro-Hungarian offensive, given that he arrived at the front after the Italian army had already been pushed back to the river Piave (Drekonja and Jankovič Potočnik 2009). The book was reviewed in the Delo by one of its then foremost journalists and cultural critics, Marijan Zlobec (2010), who adopted an interesting stance. After first acknowledging that Hemingway most likely had never set foot in the Soča valley, Zlobec closed the review wondering: "So, in spite of the scruples for a lack of evidence, is it possible that Hemingway in fact had visited the area of the former Isonzo front?" (2010). It thus seems that speculation about Hemingway's presence on Slovenian territory will tickle the imagination of Slovenian readers for some time to come.

\section{Fiftieth anniversary of Hemingway's death}

Hemingway is among the authors whose anniversaries are regularly observed by Slovenian newspapers. A good example was the $50^{\text {th }}$ anniversary of his death 
in 2011, when over ten articles appeared in Delo and Dnernik alone, most of which clustered around 2 July, the date of Hemingway's suicide. Written for the general reader, the articles typically focused on Hemingway's life and the circumstances that influenced his writing; the literary value of his work, on the other hand, was usually presented in very general terms. One such article appeared in Delo on 1 July (Grujičić 2011). Its author first dedicated considerable attention to the turning points in Hemingway's life. She mentioned his dominant mother, many encounters with suicide and death as well as Hemingway's paranoia and bouts of depression that ultimately led to his early death. Much attention was given to Hemingway's "four wives, three wars and an equal number of announcements about his death" (Grujičić 2011). Also mentioned were Hemingway's masculinity, adventurousness, cultivation of sports and his problems with alcoholism and escapism. By listing the problems that dogged Hemingway throughout his life, Grujičić adopts an affirmative position, showing compassion for Hemingway as a human being, at the same time making little reference to his writing.

Three weeks later, Delo published another extensive article, this time by Vesna Milek (2011), one of its leading cultural critics. Much like Grujičić, Milek, relying on an article published a few days previously in The Guardian, mostly focused on Hemingway's life, particularly the milestones that directly influenced his literary work. For example, the article mentioned Hemingway's days in the post-WWI "bohemian and decadent Paris", which led to the novel The Sun Also Rises and "triggered a virus that infected entire generations and gave rise to the cult of Hemingway" (Milek 2011); or the shrapnel wounds that he received on the Italian front in World War I, which gave rise to the novel $A$ Farewell to Arms. Much to the same effect, Milek interspersed the article with quotations from Hemingway, typically those that highlighted his intelligence, masculinity and cynicism. Also mentioned were his eccentricities and idiosyncrasies, such as rising before dawn to watch the matadors learn how to kill bulls in slaughterhouses or downing record numbers of cocktails to ease pain from the injuries sustained in a plane crash in Africa; not missing were the many women who surrounded him. In contrast to Grujičić, who summarized Hemingway's life in her own words, Milek made a pastiche with extensive quotations from Hemingway, his contemporaries and literary scholars. Several quotations in relation to the novel The Garden of Eden were also used to complete the article, including a passage from The Guardian, according to which Hemingway's frustration with being unable to finish the novel ultimately "killed him" (Sigal 2011).

The rest of the articles published the same year were shorter. On July 2, the date of Hemingway's death, Dnevnik announced the anniversary of his suicide in the title, highlighting his "clear, almost journalistic style that marked $20^{\text {th }}$ century 
literature" ("Ernest Hemingway, predstavnik" 2011). Two days later, Dnevnik reported that the WWI Kobarid Museum in Kobarid had marked the anniversary by displaying the first edition of $A$ Farewell to Arms. The event was attended by the then US Ambassador to Slovenia, Joseph A. Mussomeli. The article had a telling title- "Hemingway never made it to Kobarid", highlighting the debunked myth about Hemingway's visit to the area (Alič 2011). Just a day later, Dnevnik rounded off the short commemorative series with an article on Hemingway's fear of being followed by the FBI. Given that he had ties with Cuba during WWII, the FBI monitored Hemingway for several years, making him increasingly paranoid and, according to some, ultimately contributing to his suicide ("Preživljal sem najhujši" 2011). Articles such as one by Prinčič (2011), published the same year, followed the same pattern of mostly focusing on Hemingway's life.

It is common to practically all commemorative articles that they adopted a sympathetic attitude towards Hemingway, almost one of compassion. Although portraying Hemingway as a strong and fearless individual, they nevertheless particularly highlighted the fact that he was a victim of the many demons that haunted him throughout his life. In this regard, his image in the Slovenian press corresponds to that of Hemingway as a "complicated blend of bravado and fear" (Wagner-Martin 2007, 1) that he is elsewhere.

\section{Notes and other trivia}

In addition to commemorative articles, Slovenian newspapers have regularly published peripheral information about Hemingway. Such articles range from news about newly discovered letters by him, anecdotes or controversies surrounding him, to articles about his pets. Including the brief references in the "On this day in history" newspaper sections, their total number exceeds several dozen a year. Admittedly, these items have lesser literary value; nevertheless, they show that Hemingway is a cultural artefact that Slovenian editors find intriguing for their readers even more than half a century after his death.

A well-known anecdote (see Sigal 2013,105) appeared in the Dnernik on the $60^{\text {th }}$ anniversary of the liberation of Paris during WWII ("Hemingway je vkorakal”, 2004). Based half on historical evidence half on myths created by Hemingway himself, the article recounted his entry into Paris, at the time still occupied by the Nazis, highlighting Hemingway's adventurous nature. The readers thus learned that while the Allies were debating how to liberate the city without destroying it, "all that Hemingway had on his mind was his favorite bar at the Ritz hotel at Place Vendome" (ibid.). The article then describes how he took a group of war correspondents straight into the city in a Jeep, stopped in front of 
the hotel, "jumped from [the Jeep] with a pistol in his hand and (...) headed straight for the bar where he had drunk 25 years earlier with Scott Fitzgerald, ordering a bottle of extravagant Bordeaux wine that the staff had hidden from the German occupiers" (ibid.). Hemingway's literary works were not mentioned. Hemingway's macho traits were also emphasized in a long article (almost 1,400 words) published to mark 110 years of Hemingway's birth (Grizold 2009). A1though the opening paragraph mentioned Hemingway's Nobel Prize for Literature, highlighting that he "had left a mark on American and world literature" (Grizold 2009), the article nevertheless primarily is a biographical note. His life was described as "a series of adventures interrupted by periods of depression and loneliness, his final years characterized by intense suffering after he was no longer able to write" (ibid.). The prevalent tone was that of compassion. This piece mentioned Hemingway's injuries sustained in WWI, the controversies surrounding his alleged execution of POWs in WWII, his four marriages, two plane crashes that he had survived in Africa and his mental health problems preceding his death. It is notable that Grizold portrayed Hemingway as "a giant of gentle character, although attracted by wild animal hunting in Africa, deep sea fishing, bullfighting and boxing" (Grizold 2009).

Slovenian readers were also regularly updated on the various new discoveries related to Hemingway, including the marginal subjects often reported by international news agencies. Between 2007 and 2012, for example, newspapers published several reports about Hemingway's letters kept by the John F. Kennedy Presidential Library and Museum in Boston. Slovenian editors found particularly intriguing Hemingway's correspondence with the German singer and actress Marlene Dietrich, whom he had met on a French cruise ship in 1934. Endearingly calling her "my little Kraut", he kept corresponding with her until his death. Although affection was mutual, as a quote from a letter by Dietrich in the article confirms, their relationship remained platonic; according to Hemingway, this happened because they were "victims of unsynchronized passion" (Hemingway in Marlene", 2007; "Papa Hemingway", 2007). Similarly affirmative was a note on Hemingway's correspondence with Gianfranco Ivancich, whom Hemingway befriended at a bar in Venice in 1949 while discussing his war experiences. As was the case with Dietrich, this article also quotes several lines from a letter by Hemingway, this one to Ivancich about how much he misses his Italian friend. The author of the article points out that the intimate letters show the "gentle, emotional side of the otherwise strict 'macho' character that Hemingway showed to the public" ("Osebna pisma", 2012), which was important for the Slovenian readership, who were less familiar with this side of Hemingway. Slovenian readers were also informed about the discovery of previously unknown notes by Hemingway in 2007. According to the Delo, Cuban researchers found these in a villa that had for many 
years been Hemingway's home in Cuba; the phrase "unknown notes by Hemingway" in the title suggested the discovery of a possibly unknown literary piece by the famous author. However, the article then takes a somewhat unexpected turn, as it turns out that the document had no literary value, containing only information "about the writer's body weight" ("Na Kubi našli", 2007). Given the title "Hemingway's notes found in Cuba", it seems that a headline with Hemingway's name might even have been used as clickbait. The same category included at least two reports about the cats inhabiting Hemingway's house in Key West years after the writer died and which were special because "not only do they have 9 lives, they also have 6 toes" (Štravs 2007); the reports of Hemingway's alleged spying for the Soviet Union during WWII, where he apparently disappointed his commissioners "by failing to provide any useful political information" (Bratož 2009); the news about the opening of an archives with Hemingway's documents in Cuba, and many others.

\section{Hemingway book loans}

One relatively objective indicator of Hemingway's popularity among Slovenian readers in recent years is the number of loans of his books in Slovenian libraries. For the purposes of the present study, statistical data for the 1999-2019 period were analyzed, retrieved from the COBISS information system, which connects most libraries in Slovenia ${ }^{10}$. Given that the total number of editions of Hemingway's prose in book form in Slovenian exceeds 40, a selection of four representative items was analyzed: the two most widely reprinted novels: For Whom the Bell Tolls (FWTBW), with eight different editions, and A Farewell to Arms (AFTA), with five; the short novel The Old Man and the Sea (TOMATS), with three editions; the fourth item included three collections of Hemingway's short stories: the first two were published under the title The Old Man and the Sea $(1955,1969)$, while the third was entitled Big Two-Hearted River (2010) (the latter three are hereafter referred to as $\mathrm{SF})$. For each of the four groups, the annual cumulative number of book loans was established to determine the trends over the two decades. In addition, the total book loans (TBL) for all four categories over the last two decades was calculated.

The data reveal that cumulatively, the TBL for all titles and editions increased slightly between 1999 and 2019 from 1,064 to 1,265. However, the growth was

10 COBISS is a shared library cataloguing system that was introduced in the 1980 s and connects over 900 school, public, special and university libraries in Slovenia (Žnidarec 2019). By 1999, it included all public libraries in Slovenia ("Kazalci rasti" n.d.), which is why that year was the cut-off date in the survey. The author wishes to thank Anamarija Lešnik from the Institute of Information Science (IZUM) in Maribor for extracting Hemingway data from the COBISS database. 
not linear. Instead, fluctuation was evident, with a prominent increase in 20042005, when TBL quadrupled to over 4,000, mostly because of FWTBW, as is explained below. The TBL then dropped towards the median value $(1,421)$ within a year, stabilizing again. Between 2011 and 2014, TBL once again rose slightly, to just under 1,900 , after which the curve again entered a gentle but steady decrease. The curve of $F W T B W$ closely resembles that of the TBL, predominantly because $F W T B W$ in absolute terms was the most frequently borrowed work by Hemingway throughout almost the entire cycle. A spike of 4,058 TBL in 2004 appeared because the novel was put on the reading list for the 2005 general high school leaving exam for Slovenian ${ }^{11}$. The 2,500 additional loans in 2004, when students started preparing for the exam, and over 2,300 additional loans in 2005 (admittedly, some of which could have been by the same patrons) clearly show a correlation with the 8,344 students who took the Slovenian leaving exam ("Splošna matura", 2005, 18), considering that many of them very likely owned their own copy of the book ${ }^{12}$. The total number of book loans of FWTBT most likely was even higher, given that many school libraries had not yet joined COBISS by $2005^{13}$. After 2005 , the number of loans for FWTBT quickly returned to the pre-exam level (645 loans) and remained relatively stable for the next 12-13 years, with a minor rise around 2012 with 753 loans. In contrast, $A F T A$ experienced a relatively stable trend throughout the two decades. In the late 1990s, $A F T A$ was in lower demand than FWTBT, with 348 vs. 562 loans, respectively; however, the popularity of $A F T A$ gradually increased, the number of loans almost doubling to 649 in 2004; the effect was most likely caused by the reprinting of the novel in 2004 and partly as a matura epiphenomenon. The total book loans of AFTA then decreased again to the pre-2004 level (364) and remained fairly constant, with the exception of 2014, when it increased to 583 again; however, by 2019, it again dropped to the 1999 level (373).

11 In Slovenia, students intending to study at university must take the general school-leaving exam (matura) at the end of four-year high school. Two out of five exams are in elective subjects; three in mandatory, one of which is Slovenian, the mother tongue for the majority of students (or Italian/Hungarian for the members of the recognized national minorities). The written exam in Slovenian includes a literary essay either on a Slovenian literary work or a literary work from the canon of world literature; these titles are announced when students enroll in third year.

12 By and including 2005, the novel was available in eight editions in Slovenian. Unfortunately, print runs typically are not included in the colophons, so it is not possible to estimate the number of privately owned copies of the novel in Slovenia.

13 In contrast to public libraries, school libraries joined COBISS at a slower rate. For comparison: in 2005, COBISS included 26 high school libraries; by 2019, that number rose to over 90 ("Kazalci rasti" n.d.); however, the latter number includes many schools with very few or no students taking the matura exam. 
One interesting example is the novella TOMATS. Its TBL of 103 shows that it was five times less popular with readers in 1999 compared to FWTBT, which registered 562 loans. Although the popularity of TOMATS grew after the turn of the century, it was the only title in our corpus whose popularity decreased in 2004 and in 2006, reaching, in fact, its lowest point, 96 and 52, respectively. After some fluctuation, with its TBL reaching a low of 84 loans in 2010, the following year the TBL of TOMATS tripled, almost certainly because of a new translation of the novella in 2011, which soon pushed the TBL to around 300, where it remained until 2019. Finally, collections of Hemingway's short fiction (SF) shared some of the characteristics of TOMATS. The data show that SF was in the lowest demand among all four titles in 1999, with just 51 TBL per year. The numbers then grew and doubled (117) by 2003. However, as with TOMATS, the TBL again dropped in the 2004-2005 period, only to start increasing after 2006 and practically quadrupling in 2011 (544) compared to 2006 (138). Given that the collections were published under the same title as TOMATS, it is highly likely that the new edition of the novella also spurred an increase in borrowing of collections of other short fiction. However, the same trend persisted for about a year, after which the TBL for short fiction stabilized around 200, still four times that of 1999.

\section{CONCLUSIONS}

The position of Ernest Hemingway in the Slovenian literary and cultural system after 1990 has not radically changed compared to the preceding period (cf. Maver 1990). As is the case elsewhere, he remains recognized as one of the most prominent American writers (Wagner-Martin 2000, 3), both by Slovenian literary scholars and critics and among the general public. Nevertheless, a few changes can be observed. One objective difference is that the number of new book editions of Hemingway's prose has decreased. This is particularly true of new translations, given that only two new book translations were commissioned since 1990. On the other hand, reprinting old translations has not been uncommon in the same period, despite the fact that several recent studies of Slovene translations of English texts (e.g. Gadpaille and Zupan 2020; Trupej 2019; Onič 2013) have revealed that translations do age over the decades, making new ones desirable; older Slovenian translations of Hemingway are no exception. One change involves a reduction in new studies on Hemingway by established Slovenian literary scholars and critics. However, that is most likely partly connected with a decline in book editions, given that in the past, comprehensive literary essays typically accompanied or followed new book editions 
(e.g. Pirjevec 1953, 1955; Jurak 1975). On the other hand, the position of Hemingway as a cultural icon in Slovenia remains strong. In some regards, the advent of electronic media, an important vehicle for popular culture, promises that Hemingway, who was once "famous on a popular level" (Wagner-Martin 2007, 158), will fare well for some time. After all, the book loan statistical data for Slovenia over the last two decades also indicate that his works have successfully stood the test of the early $21^{\text {st }}$ century, still attracting a relatively stable cohort of Hemingway aficionados.

\section{WORKS CITED}

\section{Book editions of Hemingway in Slovenian after 1991}

Hemingway, Ernest. 1991. Zbogom, orožje! [A Farewell to Arms]. Translated by Rado Bordon. Maribor: Obzorja.

Hemingway, Ernest. 1991a. Sonce vzhaja in zahaja [The Sun Also Rises]. Translated by Bruno Hartman. Maribor: Obzorja.

Hemingway, Ernest. 1991b. Imaš in nimaš [To Have and Have Not]. Translated by Janko Moder. Maribor: Obzorja.

Hemingway, Ernest. 1991c. Zeleni griči Afrike [Green Hills of Africa]. Translated by Frančišek Mlakar. Maribor: Obzorja.

Hemingway, Ernest. 1991d. Pariz-premični praznik [Paris - A Moveable Feast]. Translated by Frančišek Mlakar. Maribor: Obzorja.Hemingway, Ernest. 1998. Komu zvoni [For Whom the Bell Tolls]. Translated by Janez Gradišnik. Ljubljana: Mladinska knjiga.

Hemingway, Ernest and Patrick Hemingway. 2000. Resnično ob prvem svitu: fiktivni spomini [True at First Light: Fictional memoirs]. Translated by Miriam Drev. Ljubljana: Gyrus.

Hemingway, Ernest. 2004. Komu zvoni [For Whom the Bell Tolls]. Translated by Janez Gradišnik. Ljubljana: Mladinska knjiga.

Hemingway, Ernest. 2004a. Zbogom, orožje! [A Farewell to Arms]. Translated by Rado Bordon. Ljubljana: Delo.

Hemingway, Ernest. 2005. Komu zvoni [For Whom the Bell Tolls]. Translated by Janez Gradišnik. Ljubljana: Mladinska knjiga.

Hemingway, Ernest. 2010. Velika reka z dvema srcema: izbrana kratka proza [Big Two-Hearted River: Selected short prose]. Translated by Janez Gradišnik and Miriam Drev. Ljubljana: Mladinska knjiga.

Hemingway, Ernest. 2011. Starec in morje [The Old Man and the Sea]. Translated by Srečko Fišer. Ljubljana: Mladinska knjiga. 


\section{References}

Alič, Jani. "Hemingway nikoli ni prišel do Kobarida." Dnernik. July 4, 2011. Accessed February 20, 2020. https://www.dnevnik.si/1042456439.

Bogataj, Matej. 2010. "Enigma Hemingway - Očka in uporni sin hkrati." In Velika reka z dvema srcema: izbrana kratka proza, Ernest Hemingway, 197-217. Ljubljana: Mladinska knjiga.

Bohanec, Franček. 1953. Hemingway gre v Kenijo. Delavska enotnost 41: 7.

Bratož, Igor. 2007. "Diletantski vohun”. Delo. July 22, 2007. Accessed February 6, 2020. https://delosled.delo.si/.

Donaldson, Scott. 1996. "Introduction: Hemingway and fame." In The Cambridge companion to Hemingway, edited by Scott Donaldson, 1-15. New York: Cambridge University Press.

Drekonja, Branko and Aleksander Jankovič Potočnik. 2009. Po sledeh Ernesta Hemingwaya. Logatec: Ad Pirum, zavod za intelektualne dejavnosti.

Fatur, Bogomir. 1936. "Dos Passos kot problem sovjetske literature." Sodobnost (4) 6: 291-96.

Gadpaille, Michelle and Simon Zupan. 2020. "Interpreting and Translating Shakespeare's Heraldic Terminology: 1 Henry IV and 2 Henry VI in Slovene." Annales Series Historia et Sociologia (30) 1: 13-34. https://doi.org/10.19233/ ASHS.2020.02.

Grizold, Adrian. 2009. "Hemingway, kronist izgubljene generacije." Slovenske novice. July 27, 2009. Accessed February 5, 2020. https://delosled.delo.si/.

Grosman, Meta. 1997. "Književni prevod kot oblika medkulturnega posredovanja leposlovja." In Knjižeroni prevod, edited by Meta Grosman and Uroš Mozetič, 11-56. Ljubljana: Znanstveni inštitut Filozofske fakultete.

Grujičić, Petra. 2011. "50 let od slovesa Ernesta Hemingwaya”. Delo. July 1, 2011. Accessed February 10, 2020. https://delosled.delo.si/.

"Ernest Hemingway, predstavnik izgubljene generacije, samomor storil pred 50 leti." 2011. Dnernik. July 2, 2011. Accessed February 20, 2020. https://www. dnevnik.si/1042456287.

Heller, Arno. 1992. "The Fading of a Legend: Hemingway's Reception in Germany and Austria." The Hemingrway Review: Special European Issue 12 (Summer): 27-35. "Hemingway in Marlene". Delo. April 4,2007. Accessed February 3, 2020. https:// delosled.delo.si/.

"Hemingway je vkorakal v svoj bar v Ritzu". Dnernik, August 26, 2004. Accessed February 3, 2020. https://www.dnevnik.si/92829.

"Honorar za scenarij." 1954. Večer, October 6, 1954, 5.

Jeranko, Branko. "Hemingwayev večni spomin na Posočje." Primorski dnevnik. January 8, 1988, 9 . 
Johnston, Rebecca. 2019. "Slovenes and Friuli as the Other in Hemingway." Acta Neophilologica 52 (1-2), 129-140. https://doi.org/10.4312/an.52.1-2.129-140. Jurak, Mirko. 1975. “Spremna beseda o avtorju.” In Komu zvoni, Ernest Hemingway, 593-611. Ljubljana: Cankarjeva založba.

"Kazalci rasti." n.d. Cobiss. https://www.cobiss.si/kazalci/. Accessed May 1, 2020. Kern Slapar, Irma. 2009. "Recepcija Hemingwayevega romana Komu zvoni na Slovenskem.” PhD diss. University of Ljubljana.

Kos, Janko. 1964. “Ernest Hemingway.” In Komu zvoni. Ernest Hemingway, 5-30. Ljubljana: Cankarjeva založba.

Kozak, Juš. 1952. "Komu zvoni?” Novi svet (1): 387-415.

Lundén, Rolf. 1992. "Hemingway in Sweden since 1965." The Hemingway Review: Special European Issue 12 (Summer): 51-62.

Matajc, Vanesa. 1998. "Poslednji prividi nesmrtnosti" In Komu zvoni, Ernest Hemingway, 491-511. Ljubljana: Mladinska knjiga.

Maver, Igor. 1990. "The old man and Slovenia: Hemingway studies in the Slovenian cultural context". Acta Neophilologica (23)1: 51-62. https://doi.org/10.4312/ an.23.1.51-62.

McIver, Bruce. 1988. "Hemingway in the Soča Valley." Acta Neophilologica (21)1: 17-19. https://doi.org/10.4312/an.21.1.

Milek, Vesna. 2011. "Ob obletnici Hemingwayeve smrti: Te preklete knjige ne morem končati." Delo. July 22, 2011. Accessed February 17, 2020. "https:// www.delo.si/zgodbe/sobotnapriloga/ob-obletnici-hemingwayeve-smrti-te-preklete-knjige-ne-morem-koncati.html.

"Na Kubi našli Hemingwayeve zapiske". 2007. Delo,June 24,2007. Accessed February 3, 2007. https://www.delo.si/kultura/na-kubi-nasli-hemingwayjeve-zapiske.html. Onič, Tomaž. 2013. "Vikanje in tikanje v slovenskih prevodih Albeejeve drame Kdo se boji Virginie Woolf?” Primerjalna književnost 36 (1): 233-252.

Orel, Boris. 1932. "Dolina meseca; roman." Dom in svet (45) 7/8:330-31.

"Osebna pisma razkrila čustveno plat Hemingwayja." Dnevnik. March 30, 2012. Accessed February 10, 2020. https://www.dnevnik.si/1042660738.

"Papa Hemingway in hčerka Marlene." Slovenske novice. April 13, 2007. Accessed March 1, 2020. https://delosled.delo.si/.

Pirjevec, Dušan. 1953. “O Hemingwayevi umetnosti." Beseda (9): 555-561.

Pirjevec, Dušan. 1955. "O ideji in kompoziciji Hemingwayeve novele Starec in morje”. In Starec in morje, Ernest Hemingway, 87-98. Ljubljana: Državna založba Slovenije.

"Pisatelji na indeksu." 1933. Ljubljanski zvon (53) 7/8: 512.

"Preživljal sem najhujši možen pekel': Je za Hemingwayev samomor kriv nadzor FBI-ja?" 2011. Dnernik. July 5, 2011. Accessed February 23, 2020. https:// www.dnevnik.si/1042456777. 
Prinčič, Špela. 2011. “Ernest Hemingway”. Delo. July 28, 2011. https://delosled. delo.si/.

Rennie A., David. 2018. "The Real British Red Cross and Hemingway's A Farewell to Arms." The Hemingway Review 37 (2): 25-41.

Reynolds, Michael. "Ernest Hemingway, 1899-1961: A Brief Biography." In $A$ Historical Guide to Ernest Hemingway, edited by Linda Wagner-Martin, 15-52. New York: Oxford University Press.

Sigal, Clancy. 2011. "Hem and us." The Guardian. June 26, 2011. Accessed February 20, 2020. https://www.theguardian.com/commentisfree/cifamerica/2011/ jun/26/ernesthemingway-fbi.

Sigal, Clancy. 2013. Hemingway lives!: Why reading Ernest Hemingway matters today. New York: OR Books.

"Splošna matura 2005: letno poročilo". 2000. Ljubljana: Državni izpitni center, november 2005. https://www.ric.si/mma/letno\%20poro\%C4\%8Dilo\%20 sm\%202005/2006070311510305/.

“Škandal okrog avtorja.” 1951. Večer, June 26, 1951, 4.

Štravs, Smilja. 2007. "Polne spominov in mačk." Delo, February 2, 2007. Accessed February 3, 2020. https://delosled.delo.si/.

Torkar, Silvo. 1992. "Hemingway in Soška fronta: kje je (ni) bil?" Delo, November 12, 1992.

Trupej, Janko. 2019. "Ideological influences on the reception of Mark Twain among Slovenians across the Atlantic." Acta Neophilologica 52 (1/2): 141-152. https://doi.org/10.4312/an.52.1-2.141-152.

"Uporaba informacijsko-komunikacijske tehnologije (IKT) v gospodinjstvih in po posameznikih, Slovenija, 1. četrtletje 2005.” 2006. Statistične informacije no. 6. Informacijska družba no. 1. January 9, 2006. Ljubljana: Statistični urad Republike Slovenije. Accessed February 15, 2020. http://uploadi.www.ris.org/ editor/1136816556SURSgospodinjstva2005.pdf.

Vernon, Alex. 2013. "War: World War I." In Ernest Hemingrway in Context, edited by Debra A Moddelmog and Suzanne del Gizzo, 388-394. Cambridge University Press.

"Zapiski." 1952. Slovenski poročevalec. March 4, 1952, 8.

Zlobec, Marijan. 2010. "Po sledeh pisatelja Ernesta Hemingwaya v Sloveniji." Delo, March 16, 2010. Accessed February 17, 2020. https://delosled.delo.si/.

Zupan, Simon. 2009. "Slogovni prevodni premiki v romanu Zbogom, orožje." $\mathrm{PhD}$ diss. University of Ljubljana.

Wagner-Martin, Linda. 2007. Ernest Hemingway: a literary life. Basingstoke: Palgrave Macmillan.

Wagner-Martin, Linda. 2000. “Introduction.” In A Historical Guide to Ernest Hemingway, edited by Wagner-Martin, Linda, 3-14. Oxford: Oxford University Press. 
Waltritsch, Marko. 1999. “Ernesta Hemingwaya v Kobaridu nikoli ni bilo.” Primorski dnervik, August 8, 1999, 12.

Winther, Per. 1992."Hemingway in Norway since 1964." The Hemingway Review: Special European Issue 12 (Summer): 20-26.

Žnidarec, Tatjana. 2019. "V letu 2018 smo zaključili projekt vključevanja šolskih knjižnic v sistem COBISS.SI.”Blog Cobiss. February 19, 2019. https://blog.cobiss.si/2019/02/19/projekt-vkljucevanja-solskih-knjiznic-v-sistem-cobiss-si/.

\author{
Simon Zupan \\ University of Maribor \\ simon.zupan@um.si
}

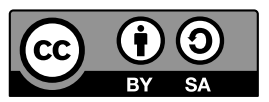

\title{
Ernest Hemingway v Sloveniji po letu 1990
}

Igor Maver (1990) je sistematično preučil status Ernesta Hemingwaya v slovenski kulturi do leta 1990. Po drugi strani pa razvoj dogajanja v slovenskem prostoru po navedenem letu zaenkrat še ni bil deležen sintetičnega pregleda. Prispevek obravnava tri vidike $\mathrm{He}-$ mingwayeve navzočnosti $\mathrm{v}$ slovenskem prostoru: literarnokritiško recepcijo njegovih del v Sloveniji po letu 1990; njegov položaj v popkulturi; in statistične podatke o izposoji njegovih del v slovenskih knjižnicah. Analiza je potrdila, da se Hemingwayev položaj $\mathrm{v}$ slovenskem prostoru ni bistveno spremenil in še vedno ostaja eden najpomembnejših ameriških piscev 20. stoletja.

Ključne besede: Ernest Hemingway, recepcija, literarna kritika, popkultura, izposoja knjig 